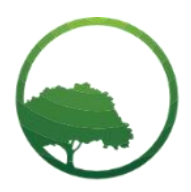

Research in Business \& Social Science

\title{
Determinants of small and medium enterprises performance with the interaction effect of managerial activities
}

\author{
Muhammad Asif Khan®(a), Marium Burki®(b) \\ (a)School of Management, Huazhong University of science and technology Wuhan, China \\ (b)Department of Public Administration, Gomal University, Dera Ismail Khan, Pakistan
}

\author{
ARTICLE INFO \\ Article history: \\ Received 30 May 20 \\ Received in revised form 18 June 20 \\ Accepted 22 June 20

\section{Keywords:} \\ Commercial Loans, Trade Credit, \\ Retain Earnings, Managerial \\ Activities, SMEs Performance \\ JEL Classification: \\ L25, L26, G20
}

\begin{abstract}
A B S T R A C T
The financial system and capital market in developed countries are more developed as compare to emerging countries. Firms like small and medium enterprise (SMEs) needs finance to operate their business and make a competitive position in the market. In an emerging country like Pakistan, SMEs face a lot of financial and non-financial obstacles that may relate to the poor performance of SMEs. This study investigates the relationship between commercial loans, retain earnings, trade credit, managerial activities, and SME's performance. This study also investigates the interaction effect of managerial activities between independent variables and dependent variables. A survey was conducted in a small and medium enterprise of KPK Pakistan. Data were collected from 362 employees. SPSS (Statistical Package for the Social Sciences) software was employed for data analysis for descriptive and regression analysis. The finding confirmed that commercial loans, trade credit, retained earning have a positive and significant impact upon SME's performance. It is also found that managerial activities have played a mediating role and increased the performance of SMEs. Among variables under study, the more trade credit activities, the higher the performance of the SMEs is observed. Based on this study's results, Leaders, supervisors, and managers are those employees having a substantial role in the performance, development, failure, and success of an organization. Managerial activities are vital for a manager for the purpose to know what should be done in different circumstances and improve overall performance and accomplish organizational goals.
\end{abstract}

(C) 2020 by the authors. Licensee SSBFNET, Istanbul, Turkey. This article is an open access article distributed under the terms and conditions of the Creative Commons Attribution (CC BY) license (http://creativecommons.org/licenses/by/4.0/).

\section{Introduction}

Small and medium enterprise (SMEs) plays a crucial role in the economic growth and development of the country. In the developing economies apart from initiating new developments, SMEs play a significant role in employment creation (Harvie \& Lee 2002; Beaver \& Prince 2004). A common growth strategy that many SMEs consider is an increase in sales of the enterprise; as a result, their profit increases, and the economic growth of the country followed. SMEs are known as a crucial factor for the economic development of the country weather countries are developed or developing (Zubair, 2014). SMEs help in delivering maintainable and comprehensive globalization. In both developed and developing countries, SMEs are considered as a focus to the policymakers for attaining the employment targets, exports, increase income level, and contributing to enhanced innovations. The presence of the SME sector has been linked with inclusive growth and development as well as environmental sustainability. SMEDA stated that in Pakistan, 99 percent of business units are small and medium, micro-enterprise, and their contribution to gross domestic product is 40 percent of the country. The contribution of SMEs to employment generation is 78 percent, which is forty percent of total job generation, which is above average among south Asian countries. Rapid globalization has increased the access of the firm to worldwide markets resulting in rapid economic growth.

SMEs have been widely considered as the economic tools that increase the growth, which results in a broad and equal distribution of wealth. SMEs increase the job opportunities, skilled labor force, and developed products for the customer at lower prices and improve the superiority of products by increasing the competition in the market place (Emine, 2012). Pakistan has been facing low economic

* Corresponding author. ORCID ID: 0000-0002-6107-8085

(C) 2020 by the authors. Hosting by SSBFNET. Peer review under responsibility of Center for Strategic Studies in Business and Finance. https://doi.org/10.20525/ijrbs.v9i4.750 
growth and development, the slow pace of trade, weak investment ratio, and rising inequality among the masses. Apart from these points government rely more on SMEs to get benefits from them and equally shared across the society and to economic divisions at all levels.

Pakistan is also an emerging country, so the role of SMEs is not more different from other countries of the world. SMEs have a great ability to grow and have the potential to make Pakistan as regional financial Hub. Pakistan can be a trade hub for investment in the private sector. However, one of the main factors facing progress is a minimal source of financing (Cowling et al. 2012). Kauser et al. (2012) stated that banks are only promoting large enterprises and not giving financing resources to small enterprises, which increased the financial gap between large enterprises and small enterprises, and about $75 \%$ of financial applications of SMEs were rejected by commercial banks. Because mostly SMEs are unable with lack of security for loans and other valuable information which forbid the financing institution to lend money. So to encounter this government should play their role and should promote SMEs business by giving them grants and loans and other facilities as much as possible. According to The State Bank of Pakistan, the supply-side data of SMEs lending is not available however demand side of borrowing obtained through interviews shows that lending to SMEs by financial institutions and banks is minimal and only meets 12 percent of SMEs financial needs. This situation is very alarming and requires policy intervention to ease the economic problems and help the SMEs to operate on their full level. Lack of adequate financing undermines the working ability of the firm and its competitiveness.

Therefore, the main objective of this study is to empirically examine the type and intensity of financial activities and their subsequent impact on firm performance. The findings of this research would significantly help policymakers in developing relevant strategies to mitigate the economic issues of SMEs operating in Pakistan. The results of this study emphasize the fundamental aspect concerning SME's failure as a lack of access to finance, lack of government policies and proper infrastructure, and other resources. These factors play a crucial role in the underdevelopment of SMEs and compromise their competitiveness.

\section{Literature Review}

The role of SMEs in economic development cannot be ignored. SMEs can be used as a tool in the promotion of productivity, competitiveness, and innovation in the national economy of the country. The distinctive role has been enacting by the SMEs to achieve socio-economic objectives like reducing poverty, producing employment opportunities, nurturing innovation, and fostering competitiveness among institutions (Shaikh \& Khoso, 2019). In both developing and developed economies, the SMEs potential in nurturing economic growth is extensively appreciated and cited by policymakers and academic scholars as well.

The SMEs contribution towards the economy has attained considerable interest from academic scholars as well as international organizations whose aim at triggering the SMEs growth via using public polices, thus enhancing the economic performance in general. In developing economies, SMEs are considered a significant contributory factor in eradicating poverty of the country and sponsoring value addition to the locally manufactured goods (Avendano, 2013). Though there are certain factors identified by numerous scholars that hinder the SMEs to operate and perform smoothly, which may lead to their failure and some of these, do not up to the optimal level. For example, prior literature has indicated that SMEs have limited access to the financial resources when compared to the larger and established firms, which can affect infrastructure, financial and technological supports on the SMEs performance (Adaramola, 2012). This study investigates the impact of financial resources options in terms of Commercial loans financing and trade credit financing, and managerial activities on the performance of SMEs in the context of Pakistan.

\section{Managerial Activities}

The managerial activities by both managers and owners of SMEs can influence the performance and growth of SMEs. Prior studies are indicating that the growth and performance of SMEs are directly influenced due to the lack of managerial activities like lack of skills and knowledge about business in managers and owners of SMEs (Prijadi \& Desiana, 2017). The owners and managers may confront problems of not using the available human resources effectively, limited access to external finance, and hindrances to manage other resources of the enterprise to obtain optimum output and achieve the organizational objectives effectively and efficiently. Botha (2006) affirmed that insufficient performance and failure of SMEs are mainly caused due to owners and managers with limited managerial skills related to the management of the human resource, marketing, and financial activities. Thus the managers and owners with enhanced business skills are an essential factor in the success, growth, and survival of SMEs in the context of developing and less developed economies.

It was emphasized that insufficient level of managerial skills leads towards the failure of SMEs (Safiriyu \& Njogo, 2012), while managers and employees with sufficient and advanced levels of managerial skills impact the performance of firms in a positive direction (Hussain, 2000). The implications of Hussain (2000) were confirmed by Solomon (2004) and affirmed that skills related formation of financial reports and marketing strategies is essential in the growth of firms. The managerial skills related to finance and credit is also crucial in the survival and growth of SMEs. The owners and managers with the optimal managerial skills are the critical determinants in the development and growth of SMEs (Kuene, 2009). Based on the above discussion, we developed the following hypothesis;

H1: There is a positive and mediation relationship of managerial skills between independent variables and SMEs performance 


\section{Trade credit financing}

The credit extended by the suppliers against the goods and services purchased by SMEs on a credit basis for a specified period, which must be paid by the SMEs in the given period, is known as trade credit (Munyany, 2013). Trade credit plays a vital role in the smooth running and growth of SMEs. The conditions in developed economies support the SMEs in financing via trade credit as compared to underdeveloped and developing countries as it was cited by various authors that trade credit financing of SMEs in the USA is about one-third of the same sector. It is equal to the funding via commercial banks in the USA, while financing via trade credit by SMEs in Japan comprises of almost 23 percent (Taketa \& Udell (2007).

The financial contracts in the developing and underdeveloped countries are challenging to enforce due to the weak financial and legal systems. The financial constraints of SMEs can be retrieved via trade credit, as it is one of the vital sources of financing. The tradecredit was the dominant source of finance in the times of financial crises in Japan. In developing economies, a suitable source of financing is trade credit as the creditworthiness of the firms is weak; thus, such firms cannot acquire loans from financial institutions. Financing via trade credit is beneficial as it concedes SMEs to avail discounts, lowers the costs of borrowing, and it a less risky source of finance (Munyany, 2013). Xiao (2014) emphasized that SMEs operating in developing countries and utilizing trade credit showed better and faster growth. The Latvian SMEs fostered trade credit over time. SMEs with weak financial position also option for trade credit in the developing economies. Based on the discussion above, it can be witnessed that trade credit is an essential source of financing. Thus we developed the following hypothesis;

$\mathrm{H} 2$ : There is a positive relationship trade credit financing between and SMEs performance

\section{Commercial loans financing}

Commercial loans are the funds obtained on credit from different sources like banks, individuals, and other institutions for the smooth running of SMEs operations (Munyany, 2013). Some specific terms and conditions are associated while obtaining funds through commercial loans. Commercial loans are considered as a vital source of financing as funds can be utilized in business expansion, and acquiring new and advanced equipment and technology (Mishra \& Soota, 2014). Xiao (2014) highlighted that firms engaged in financing their sources via commercial could minimize their financial distress, options to finance new projects to generate new cash flows. Quianoo (2011) acknowledged that the financial performance of SMEs is associated with commercial loans.

The main issues faced by the financial institutions to grant commercial loans on large scales are weak management of SMEs, minimum financial information, low creditworthiness, complicated process to register, and lack of governance (Odongo, 2014). The long-term loans are preferred by financial institutions as minimum administrative costs are associated with it (Rosenberg et al., 2009) while SMEs prefer short term loans to finance their resources for immediate needs as SMEs cannot utilize the more significant amount which may create financial distress thus leading to failure of SMEs (Jun et al., 2003). The relationship among borrowers and lenders can be enhanced due to frequent renewals of short-term financing. Thus, SMEs can enjoy exceptional credit benefits (Ozkan, 2000).

Long-term loans are also a significant source of financing. But SMEs cannot acquire long-term debt because of having limited assets. Thus SMEs are unable to finance their projects by borrowing funds, which can be identified as the potential factor in the expansion and growth of SMEs. Pelham (2000) narrated that larger firms can enjoy more benefits of long-term financing as compared to SMEs and reported a significant and positive link of commercial loans with the performance of firms. Based on the discussion above, we developed the following hypothesis;

H3: There is a positive relationship trade commercial loans financing between and SMEs performance

\section{Methodology}

\section{Research design}

Kombo \& Tromp (2006) explained that research design as the box that puts all the components in the research project together. This study was based on a descriptive research design. This survey tries to collect information from a specific group upon conclusions are drawn about the behavior of the target population. Its goals are to find reasons why a particular activity is happening (Zikmund, Babin, Carr \& Griffin, 2010). This research design is suitable for answering questions on the current state of matters (Stangor, 2011). This design attempts to describe things like values, behaviors, attitudes, and characteristics, and it allows for the collection of information, which enables the researchers to generalize the finding to a large population (Mugenda \& Mugenda, 2003). The advantage of this kind of survey is that they increase the rapid collection of data that are accurate, economical, efficient and can easily be assessing the information about the target population and less rigid in their application (Hart, 2005). This type of survey is a most suitable design for this kind of study because this study was used to get fact-finding inquiry hence required an explanation of current study after which the result would be generalized to whole target study (Siekei et al., 2013).

\section{Research philosophy}

It is a faith of how data about any event should be gathered, organized, analyzed, and used. Ihuah \& Eaton (2013) stated that there are three main research philosophies, which include constructivist, epistemology, and positivism. The underlying philosophy that 
guides the social researcher is positivism. Jackson (2013) stated that epistemology poses a question on what is the association between the knower and what is known. Constructivist philosophy sees the world that it is constructed, interpreted, and experienced by people in their dealing with each other and with the social system. It views and belief that in the external world, the truth and meaning do not exist but are created by the subjects dealing with the world, showing that it is constructed but not discovered. Antwi \& Hamza (2015) stated that the purpose of the investigation is to understand the particular activity not to generalize the population. Ihuah $\&$ Eaton, (2013) positivism is a philosophy of science that seeks evidence of social phenomena with little regard for the subjective status of the individual. Positivism says that facts and reality exist external to the researcher and must be investigated through the demanding process of scientific investigation. It believes that the world is independent of our knowledge of it, "it exists out there." Antwi \& Hamza, 2015 stated that the study used by positivist philosophy, which supports an objective clarification of reality using data from a survey that is formal, structured, and has a specific and detailed plan. The collection of data focuses on the collection of data in hard from that enables evidence and proof to be presented in quantitative form. Ihuah \& Eaton (2013) stated that the researcher who works from the positivism approach explains in quantitative terms how variables interact with one another, makes the event, and causes outcomes. In this approach, the researcher and research are independent upon each other, and this research can be done or measured by using questionnaires (Ihuah \& Eaton, 2013).

\section{Population and sample size}

According to (Khaemba, Manase, Musiega, \& Kimani, 2013), the target population is a structure of units from which the sample is to be selected and obtained. Kombo \& Tromp (2006) stated that a sample is a group of individuals, events taken from the general population having similar features. The population for this study is small and medium enterprises of Khyber Pakhtunkhwa Pakistan. It is just a small group but a true representative of the whole population. The sample of 362 respondents was used for analysis.

\section{Data analysis}

Kombo \& Tromp (2006) stated that data analysis states to analyzing what has been gathered in a survey and drawing results, conclusion, and interpretation. Mugenda \& Mugenda (2003) stated that raw data collected from the field is useless until it is properly arranged, classified, summarised, and analyzed. Both the descriptive and inferential statistics helped in data analysis. Correlation and regression technique was used in inferential statistics to know the effect of an independent variable on the dependent variable.

\section{Results and discussion}

Figure 1 shows the demographic variables of the study. The gender variables show that there are more male employees compare to females. The statistics show that more employees are having marital status single, while the number of married employees is 150 , which shows that more young peoples are working in these sectors. The education variable indicates that the number of employees has more than fourteen years of education, while only 97 employees are having less than 14 years of schooling, which confirms that small and medium enterprises provide jobs to young youth of the countries. Similarly, most of the SMEs are run by owners of the firms, and the pie chart shows that the number of SMEs run by the owner is 223, while 139 SMEs are run by the managers on behalf of their owners. As we know that small and medium enterprises play a crucial role in the development of the country, so the government is giving more incentives to established the SMEs and the outcomes shows that most of SMEs have less than five years of business while only 120 firms are having more than five years of business, so it shows that SMEs are established in significant number during recent years.

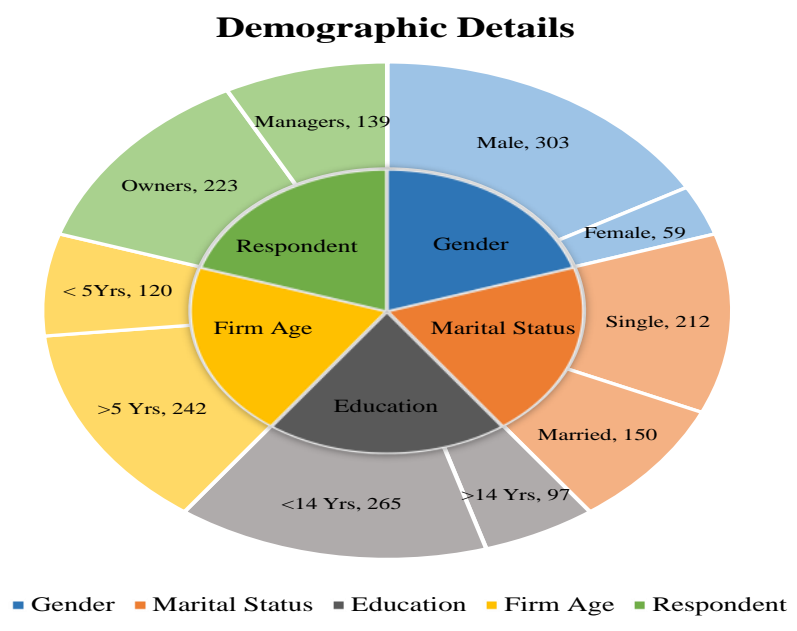

Figure 1: Demographic Statistic 


\section{Descriptive statistics of sample size}

Table 1 shows the descriptive statistics of the variables under the study. The SMEs performance is taken as the dependent variable while commercial loans, trade credit is considered as an independent variable and managerial activities as a mediating variable. The total number of sample size is 362 . The table also shows that the mean value is highest for managerial activities among all variables. Table 1 shows that for managerial activities, the mean value is 4.03 with standard deviation 0.60 ; for trade credit, the mean value and standard deviation is 3.71 and 0.54 . While for SMEs performance, the mean value is 3.91, with a standard deviation of 0.60.

Table 1 Descriptive statistics

\begin{tabular}{lllll}
\hline Variables & Commercial loans & $\begin{array}{l}\text { Managerial } \\
\text { activities }\end{array}$ & Trade credit & SMEs performance \\
\hline Mean & 3.68 & 4.03 & 3.71 & 3.91 \\
\hline Maximum & 4.50 & 5.90 & 4.60 & 4.88 \\
\hline Minimum & 1.30 & 1.90 & 1.50 & 1.75 \\
\hline Standard deviation & 0.46 & 0.60 & 0.54 & 0.60 \\
\hline Observations & 362 & 362 & 362 & 362 \\
\hline
\end{tabular}

\section{Correlation Statistics}

Table 2 shows the correlation matrix of the research variables under the study. The outcome indicates that all the variables are positively and significantly correlated with one another. The table shows that the correlation between trade credit and commercial loans is .70, which shows they affect each other by seventy percent. Similarly, the relationship between commercial loans, managerial activities, and SMEs performance is 42 percent and 59 percent, respectively. The correlation between trade credit and SMEs performance is 72 percent, while managerial activities affected SMEs performance by 64 percent. The table shows that all the variables are significantly and positively correlated with each other at a 0.05 significance level.

Table 2: Correlations results

\begin{tabular}{lllll}
\hline VARIABLES & CL & TC & MA & SMEs (FP) \\
\hline Commercial Loans $(\mathbf{C L})$ & 1 & & & \\
\hline Trade credit $($ TC) & $.706^{* *}$ & 1 & 1 & \\
\hline Managerial activities (MA) & $.424^{* *}$ & $.720^{* *}$ & $.640^{* *}$ & 1 \\
\hline SMEs performance (FP) & $.594^{* *}$ & $.726^{* *}$ &
\end{tabular}

NOTE $* * P=<0.05$

\section{Regression Analysis}

Table 3 shows the regression analysis of the independent variable and dependent variable. In model one, commercial loans and trade credit is an independent variable, while SMEs is the dependent variable. In model 2, managerial activities act as a mediating variable in between dependent variable and independent variable. The $\mathrm{R}$ square value for model one is .54, which means that model has 54 percent explanatory power, while R square for model 2 is .57 , which shows that they are explaining the dependent variable by 57 percent, so managerial activities are playing a meditating role in between independent variable and dependent variables. The outcome of table 3 shows that all the variables are positively and significantly associated with SMEs performance. 
Table 3: Hierarchical regression

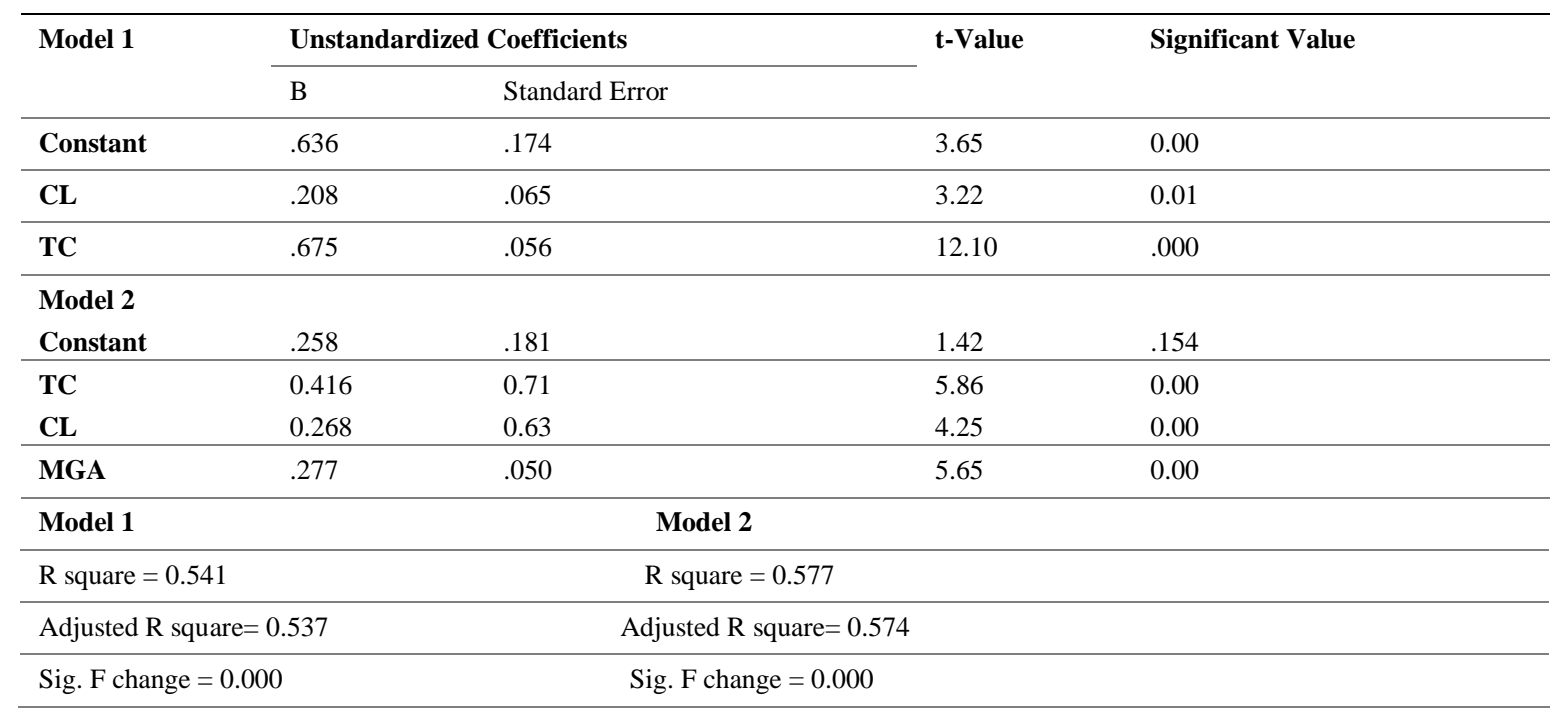

\section{Table 4 Stepwise model}

Table 4 shows the stepwise mediation model for the independent variable and dependent variable. The outcome of the model indicates that managerial activities play a mediating role between commercial loans, trade credit, and small and medium enterprises' performance. It increases the effective use of commercial loans and trade credit as the result of this the SMEs performance increases.

\begin{tabular}{llll}
\hline Model & Variables & Results & Remarks \\
\hline $\mathbf{1}$ & . [IV-MV] & $\mathrm{B}=-.216, \mathrm{P}=.002$ & Significant impact \\
& & $\mathrm{B}=.933, \mathrm{P}=.000$ & Significant impact \\
\hline $\mathbf{2}$ & . [MV-DV] & $\mathrm{B}=.634, \mathrm{P}=.000$ & Significant impact \\
\hline $\mathbf{3}$ & . [IV-DV] & $\mathrm{B}=.208, \mathrm{P}=.001$ & Significant impact \\
& & $\mathrm{B}=.675, \mathrm{P}=.00$ & Significant impact \\
\hline Final & {$[\mathrm{IV}-\mathrm{MV}-\mathrm{DV}]$} & $\mathrm{B}=.268, \mathrm{P}=.000$ & Significant impact \\
& & $\mathrm{B}=.416, \mathrm{P}=.000$ & Significant impact \\
& & $\mathrm{B}=.277, \mathrm{P}=.000$ & Significant impact \\
\hline
\end{tabular}

Note IV= independent variable, $\mathrm{MV}=$ mediating variable, $\mathrm{DV}=$ dependent variable

\section{Conclusions}

The results provide the relevant background of what are the main obstacles that affect the performance of Small and medium enterprises. The main objective of this study is to examine the impact of commercial loans, trade credit, and managerial activities on small and medium performance. The study also studied the mediating role of managerial activities in between variables. The outcome of the study shows that there are more male workers compare to female workers, the demographic shows that more workers are unmarried and having more than fourteen years of education, which shows that small and medium enterprises are providing job opening to young ones. There are more new firms as compare to older ones, which shows that the government is providing facilities to open new enterprises which will boost the economy of the country. Table one shows that the number of observations is 362 and show that the highest mean value for managerial activities and the lowest standard deviation for commercial loans. Table 2 shows that there is a positive and significant correlation between the independent variable and dependent variables. The regression analysis indicates that managerial activities are playing a mediating role between commercial loans, trade credit, and SMEs performance. The $\mathrm{R}$ square of the model moves upward from 54 to 58 percent, which shows that managerial activities are playing a mediating role between variables. The increase in $\mathrm{R}$ square indicates that managerial activities have increased the effective use of commercial loans and trade credit, which in turn increases the performance of SMEs. The outcome of table 3 shows that there is a positive and significant association between trade credit and SMEs performance $(\beta=.41, \mathrm{p}=0.00)$. So this finding is similar to the outcome of Gupta et al. (2015), which stated that trade credit has a positive impact on SMEs performance. As in this competitive world, it is difficult for small firms to survive, so large firms should give trade facilities to the firm to make their business smoothly. Table 3 shows that there is strong association between commercial loans and SMEs performance $(\beta=.26, p=0.00)$. So the government should provide easy loan facilities to SMEs to meet their financial obligations. Free or fewer interest loans to SMEs, subsidies, and 
other financial benefits should be provided by the government to encourage SMEs business. This outcome is similar to the outcome of (Ubesie et al., 2017). The findings show that managerial activities have a positive and significant impact on SMEs performance $(\beta=.27, p=0.00)$, which shows any change in managerial activities will bring change in SMEs performance by 27 percent. These findings are supported by the findings of (Agyei-Mensah, 2011). The findings also show that managerial activities have to play a mediating role between trade credit, commercial loans, and SMEs performance.

SMEs is competently used as a tool for promoting production, innovation, and helps the country economy to maintain a high level. Across the globe, the SMEs have been playing a key role in the development of the country and achieving a social and economic objective such as an increase in employment openings, poverty reduction, equal distribution of wealth, and attaining competitiveness of the institution (Ndiaye, Razak, Nagayev, \& Ng, 2018). The outcomes show that CL, TC, and MA have a positive impact on firm performance, so the firm owner and manager must have enough knowledge about how to use these resources for the development of SMEs. The financial system of Pakistan is not friendly for SMEs and bank, and lending institution hesitates to give commercial loans to SMEs so the government should give special attention to SMEs in its policy frame and launch the policy that eases the problems related to finance so that SMEs could work with their potential. The government should develop special banks and financial institutions that can provide financial assistance and provide at a low cost. Retain earning is the other financing for SMEs growth, but the problem is with the decision of how much amount should be retained for future expansion of the business. Hence, the owner or the manager has to decide how much amount should be kept back in the business. Our results also show that trade credit has a significant impact on the performance of SMEs. However, for smaller and medium enterprises, it is difficult for them to obtain trade credit from suppliers because they usually get their supplies on cash, not on delay payments, so it affects their business. Managerial activities are essential for the success and development of SMEs as our analysis shows that it increases the performance of the SMEs because the management has to decide which resource should be worthy for the growth of SMEs. Hence, it is crucial for SMEs that they must have knowledge and skill full management because they will make different decisions regarding SME's financing.

\section{References}

Adaramola, A. O. (2012). Policy support and performance of small and medium scale enterprises in South-West Nigeria. European Journal of Business and Management, 4(9).

Agyei-Mensah, B. K. (2010). Financial management practices of small firms in Ghana: An empirical study. African Journal of Business Management 5(10), 3781-3793, http://dx.doi.org/10.2139/ssrn.1597243

Antwi, S. K., \& Hamza, K. (2015). Qualitative and quantitative research paradigms in business research: A philosophical reflection. European journal of business and management, 7(3), 217- 225.

Beaver, G., \& Prince, C. (2004). Management, strategy and policy in the UK small business sector: a critical review. Journal of small business and enterprise development.

Botha, M. (2006). Measuring the effectiveness of the women entrepreneurship programme, as a training intervention, on potential, start-up and established women entrepreneurs in South Africa (Doctoral dissertation, University of Pretoria).

Ejermo, O. and Xiao, J. (2014). Entrepreneurship and survival over the business cycle: how do new technology-based firms differ?. Small Business Economics. Springer, 43(2), 411-426. https://doi.org/10.1007/s11187-014-9543-y

Emine, D. (2012). Financial challenges that impede increasing the productivity of SMEs in Arab region. Journal of Contemporary Management, 1(9), 17-32.

Friesner, T., \& Hart, M. (2005). Learning logs: Assessment or research method. The electronic journal of business research methodology, 3(2), 117-122

Gupta, J., Gregoriou, A. and Healy, J. (2015) 'Forecasting bankruptcy for SMEs using hazard function: To what extent does size matter?', Review of Quantitative Finance and Accounting. Springer, 45(4), 845-869. https://doi.org/10.1007/s11156-014$0458-0$

Harvie, C., \& Lee, B. C. (2002). East Asian SMEs: Contemporary Issues and Developments-An Overview. The role of SMEs in national economies in East Asia, 1-20.

Hussain, M. N., \& Planning, S. (2000). Linkages between SMEs and large industries for increased markets and trade: an African perspective.

Ihuah, P. W., \& Eaton, D. (2013). The pragmatic research approach: A framework for sustainable management of public housing estates in Nigeria. Journal of US-China Public Administration, 10(10).

Jackson, M. B. (2013). Conceptual analysis and epistemic progress. Synthese, 190(15), 3053-3074

Kombo, D. K., \& Tromp, D. L. (2006). Proposal and thesis writing: An introduction. Nairobi: Paulines Publications Africa, 5, 81430.

Kouser, R., Durani, A., Hussain, F. Z., \& Hassan, M. (2012). Investigation of banker's lending criteria to SMEs and assessment thereof. International Research Journal of Finance and Economics, 4(89), 158-186.

Khaemba,S.B., Manase,W.G., Musega,D.,\&Chege,K.(2013). The role of communication in enhancing Kenyan public university performance: A case study of MasindeMuliro University of Science and Technology. International Journal for management Science and Technology (IJMST), 1(4), Paper-3.

Kunene, T. R. (2009). A critical analysis of entrepreneurial and business skills in SMEs in the textile and clothing industry in Johannesburg, South Africa (Doctoral dissertation, University of Pretoria). 
Lee, N., Sameen, H., \& Cowling, M. (2015). Access to finance for innovative SMEs since the financial crisis. Research policy, 44(2), 370-380. https://doi.org/10.1016/j.respol.2014.09.008

Li, J., Zhang, Y. and Matlay, H. (2003). Entrepreneurship education in China. Education + Training, 45(8/9), 495-505. https://doi.org/10.1108/00400910310508883

Mishra,C.R.,\&Soota, T. (2014). Second edition reprint. Modern project management.New Age International (P) Ltd., Publishers.

Munyuny, C. T. (2013). Effect of debt financing on performance of small \& medium enterprises in Eldoret Municipality.

Mugenda, O. M., \& Mugenda, G. A.(2003). Research methods Quantitative and qualitative approaches Nairobi ACTS press

Ndiaye, N., Razak, L. A., Nagayev, R., \& Ng, A. (2018). Demystifying small and medium enterprises'(SMEs) performance in emerging and developing economies. Borsa Istanbul Review, 18(4), 269-281.

Odongo, J. (2014). Lending terms and financial performance of small medium enterprises in Uganda: Case of Soroti District. Research Journal of Finance and Accounting: www. iiste. org ISSN 2222-1697.

Ozkan, A. (2000). An empirical analysis of corporate debt maturity structure. European Financial Management, 6(2), 197-212. https://doi.org/10.1111/1468-036X.00120

Pelham, A.M. (2000). Market orientation and other potential influences on performance in small and medium-sized manufacturing firms. Journal of Small Business Management, 38(1),48-67.

Prijadi, R., \& Desiana, P. M. (2017). Factors Affecting the Profitability and Growth of Small \& Medium Enterprises (SMEs) in Indonesia. International Journal of Economics \& Management, 11.

Quainoo, T. K. (2011). Examining the impact of loans on SMEs in Ghana. The Institute of Distance Learning, Kwame Nkrumah University.

R Avendano, Boehm, E Calza Why scarce small and medium enterprise financing hinders growth in Latin America Journal of the Role for Public Policies, 2(2), 112 - 114.

Rosenbusch, N., Brinckmann, J. and Bausch, A. (2011). Is innovation always beneficial? A metaanalysis of the relationship between innovation and performance in SMEs. Journal of business Venturing. 26 (4), 441-457.

Safiriyu, A. M., \& Njogo, B. O. (2012). Impact of small and medium scale enterprises in the generation of employment in Lagos State. Kuwait chapter of Arabian journal of business and management review, 33(847), 1-35.

Siekei, J., Wagoki, J., \& Kalio, A. (2013). An assessment of the role of financial literacy on performance of small and micro enterprises: Case of Equity Group Foundation training program on SMEs in Njoro District, Kenya. Business \& Applied Sciences, 1(7), 250-271.

Shaikh, S., \& Khoso, I. U. (2019). Impact of Financial Constraints on the Performance of SMEs-A Study of Sindh Province. Journal of Independent Studies \& Research: Management \& Social Sciences \& Economics, 17(1).

Solomon, T. G., Winslow, K. E., \& Tarabishy, A. (2004). The role of climate in fostering innovative behavior in entrepreneurial SMEs. Retrieved October 4, 2005.

Stangor, C. (2011). Research methods for the behavioral sciences.(Laureate Education, Inc., custom ed.).

Taketa, K. and Udell, G. F. (2007). Lending channels and financial shocks: The case of small and medium-sized enterprise trade credit and the Japanese banking crisis. Monetary and Economic Studies. Institute for Monetary and Economic Studies, Bank of Japan, 25(2), 1-44.

Ubesie, M. C., Onuaguluchi, I. F. and Mbah, A. M. (2017). Effect of deposit money banks credit on small and medium-scale enterprises growth in Nigeria. International Journal of Finance and Accounting, 6(5)117-132.

Zikmund, W. G., Babin, B. J., Carr, J. C., \& Griffin, M. (2010). Business Research Methods, South Western. Cengage Learning.

Zubair, A. K. I. (2014). Entrepreneurship and Economic Development in Nigeria: Evidence from Small and Medium Scale Enterprises (SMEs) Financing. 